\title{
Integrasi QRIS pada Aplikasi Donasi Elektronik Berbasis Web di Masa Pandemi Covid-19
}

\author{
Anggi Mardiyono1), Ariawan Andi Suhandana ${ }^{2)}$, Rahmanita Vidyasari ${ }^{3)}$ \\ 1,2Jurusan Teknik Informatika dan Komputer, Politeknik Negeri Jakarta \\ ${ }^{3}$ Jurusan Akuntansi, Politeknik Negeri Jakarta \\ Correspondence author: Anggi Mardiyono, email : anggi.mardiyono@tik.pnj.ac.id. \\ DOI: https://doi.org/10.37012/jtik.v7i1.526
}

\begin{abstract}
Abstrak
Penelitian ini menjelaskan tentang integrasi Quick Response Code Indonesian Standard (QRIS) dengan aplikasi donasi elektronik sebagai alat penggalangan infak di lingkup masjid binaan Dewan Masjid Indonesia (DMI) Kota Depok. Dampak yang diakibatkan oleh adanya pandemi COVID-19 ini secara tidak langsung berpengaruh terhadap pemasukan masjid di Kota Depok dan para Kiyai yang sering berdakwah di lingkungan masjid. Aplikasi ini dikembangkan berbasis web yang menyediakan fitur infak bagi masyarakat yang akan berdonasi ke masjid tanpa harus memasukkan uang ke dalam kotak infak di masjid. Aplikasi ini memfasilitasi pembayaran elektronik dengan mengintegrasikan QRIS pada saat akan melakukan transaksi elektronik. QRIS juga dapat langsung dipindai dari laman web secara langsung tanpa harus dicetak. Hasil dari pindai pada aplikasi ini akan membaca rekening nomor tujuan dari pengelola masjid. Metode yang digunakan dalam pengembangan aplikasi ini adalah Metode Software Development Life Cycle (SDLC).
\end{abstract}

Kata Kunci: e-donasi, COVID-19, SDLC, QRIS, Web

\begin{abstract}
This paper describes the integration of the Indonesian Standard Quick Response Code (QRIS) with the electronic donation application as a tool of collecting social donation for helping the mosques which are part of the Depok's Indonesian Mosque Council (DMI). The impact caused by the COVID-19 pandemic indirectly affects the entry of mosques in Depok City and the Kyai who often preach in the mosque environment. This application was developed based on a web that provides an infaq feature for people who will donate to the mosque without having to put money in the donation box at the mosque. This application facilitates electronic payments by integrating QRIS when conducting electronic transactions. QRIS can also be scanned directly from a web page directly without having to be printed. The results of the scan in this application will read the destination account number from the mosque manager. The method used in developing this application is the Software Development Life Cycle (SDLC) method.
\end{abstract}

Keywords: e-donation, COVID-19, SDLC, QRIS, Web

\section{PENDAHULUAN}

COVID-19 telah menjadi wabah besar pada tahun 2020 dibelalahan dunia termasuk Indonesia. Pandemi COVID-19 masih berlanjut di tahun 2021 ini. Salah satu cara yang dapat dilakukan untuk mengurangi penyebaran virus ini adalah dengan menerapkan protokol kesehatan yang ketat. Salah satu protokol kesehatan yang wajib diterapkan 
adalah mengurangi kerumunan atau pysical distancing. Larangan bepergian diterapkan hampir disetiap negara [1]. Pandemi ini menyebabkan dampak terhadap daya beli masyarakat menjadi menurun akibat kelangkaan produksi karena berhentinya proses produksi oleh negara-negara raksasa manufaktur seperti Cina dan Amerika [2]. Dampak ekonomi yang ditimbulkan salah satunya adalah meningkatnya angka pengangguran [3]. Penyaluran bantuan dibutuhkan untuk menjaga agar masyarakat tetap dapat hidup sehat dan meningkatkan kekebalan tubuhnya dari serangan penyakit. Tubuh manusia akan dapat bertahan dari serangan penyakit apabila asupan gizi baik dan sistem imun dalam tubuhnya bekerja dengan baik. COVID-19 ini diketahui dapat menyerang sistem imun pada manusia [4].

Dampak sosial lain yang diakibatkan adanya pandemi ini adalah rumah-rumah ibadah tanpa terkecuali masjid yang menjadi sepi pengunjung dan dikuranginya jumlah jamaah yang dapat beribadah langsung di masjid. Dampak ini menyebabkan beberapa kegiatan dakwah di masjidpun ikut serta dibatasi untuk akses langsung dengan jamaahnya. Teropak infak yang menjadi salah satu pemasukan masjid menurun drastis di masa pandemi ini diakibatkan sumbangan dari para jamaah yang berkurang. Biaya operasional masjid juga sangat dipengaruhi oleh pemasukan infak para jamaahnya. Beberapa ustadz yang menjadi narasumber di beberapa kegiatan dakwah di masjid terkena imbas menurun pendapatannya dari akibat kegiatan pengajian rutin yang sering diadakan di masa pandemi tidak bisa mengadakan pengajian lagi secara langsung. Aplikasi berupa donasi online memberikan solusi sosial di China dalam membantu menangani kemiskinan [5]. Dewan Masjid Indonesia (DMI) Kota Depok sebagai pembina masjidmasjid di wilayah Depok mendapati kenyataan pahit bahwa beberapa masjid-masjid di bawah binaan DMI ini terancam tidak dapat membiaya operasional masjid, para ustadz, dan para penjaga masjid yang beberapa diantara mereka tidak memiliki mata pencaharian lainnya. Berangkat dari problematika tersebut, Politeknik Negeri Jakarta melalui lembaga pengambian masyarakat menjalin kerjasama dengan DMI Kota Depok guna mengembangkan suatu aplikasi yang dapat digunakan sebagai informasi kepada masyarakat terkait dengan penyaluran infak dan sedekah yang masih dapat diberikan di masa pandemi ini tanpa harus datang langsung ke masjid-masjid di wilayah sekitarnya.

Aplikasi yang dikembangkan ini menggunakan QR Code khusus untuk donasi yang akan disebarluarkan melalui situs online. Teknologi QR Code telah banyak digunakan dalam transaksi pembayaran elektronik. Teknologi ini telah banyak digunakan secara luas di berbagai industri untuk keamanan transmisi transaksi data [6]. Seiring dengan diterbitkannya standar pembayaran dengan QR Code oleh Bank Indonesia, maka aplikasi yang akan dikembangkan ini hanya menampilkan QR Code yang sudah terstandard yaitu QRIS (QR Code Indonesian Standard). Dengan QRIS ini, masyarakat yang akan berdonasi ke masjid cukup men-scan QRIS dengan aplikasi digital payment yang 
dimilikinya tanpa harus berpindah ke aplikasi lain secara khusus. QRIS ini memberikan solusi kekhawatiran akan adanya penipuan yang mengatasnamakan masjid atau Dewan Masjid Indonesia di Kota Depok.

\section{METODE}

Metode penelitian yang digunakan dalam penelitian ini terlihat pada Gambar 1. Langkah dalam metode penelitian meliputi Analisis Masalah, Studi Literatur, Pengumpulan Data, Pengembangan, dan Penyampaian Produk. Tahap pengembangan dalam penelitian ini mengadopsi metode pengembangan pada perangkat lunak dengan menggunakan metode Software Development Life Cycle (SDLC). Metode ini cukup populer digunakan dalam pengembangan suatu aplikasi. Metode SDLC ini menjadi bagian yang sangat signifikan dalam mendapatkan kebutuhan pengembangan perangkat lunak [7]. SDLC ini memiliki beberapa jenis dan yang umum digunakan adalah Model Waterfall. Metode ini diperkenalkan pertama kali pada tahun 1970 oleh Winston Royce [8].

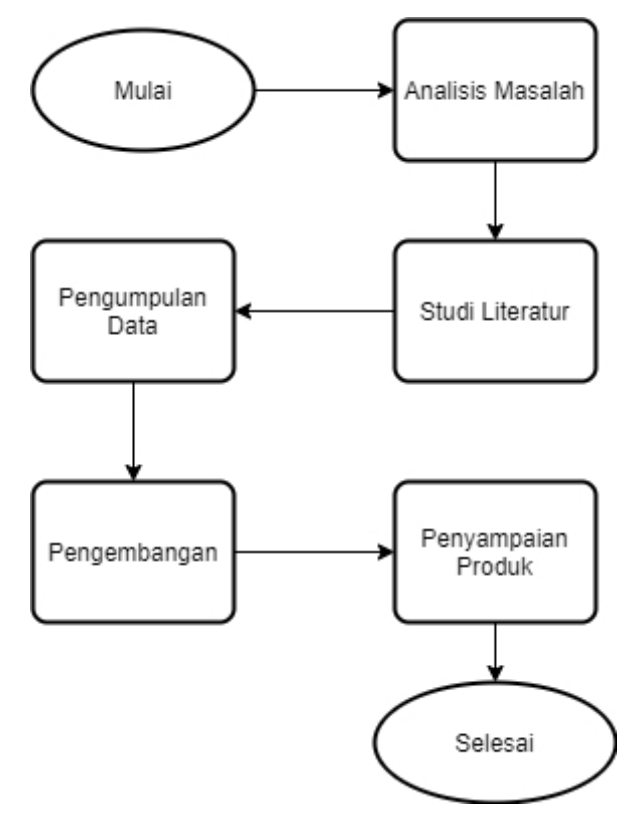

Gambar 1: Metode Penelitian

Fase pengembangan pada metode penelitian tersebut mengadopsi metode pengembangan SDLC. Metode SDLC yang dipilih yakni Model Waterfall. Metode memiliki proses yang sekuensial [9]. Metode ini memiliki beberapa tahap yang terlihat pada Gambar 2. Metode ini dipilih karena waktu pekerjaan proyek ini singkat dan relatif minim perubahan. Kemudahan dan kesederhanaan menjadi salah satu kelebihan dari metode ini 
[10].

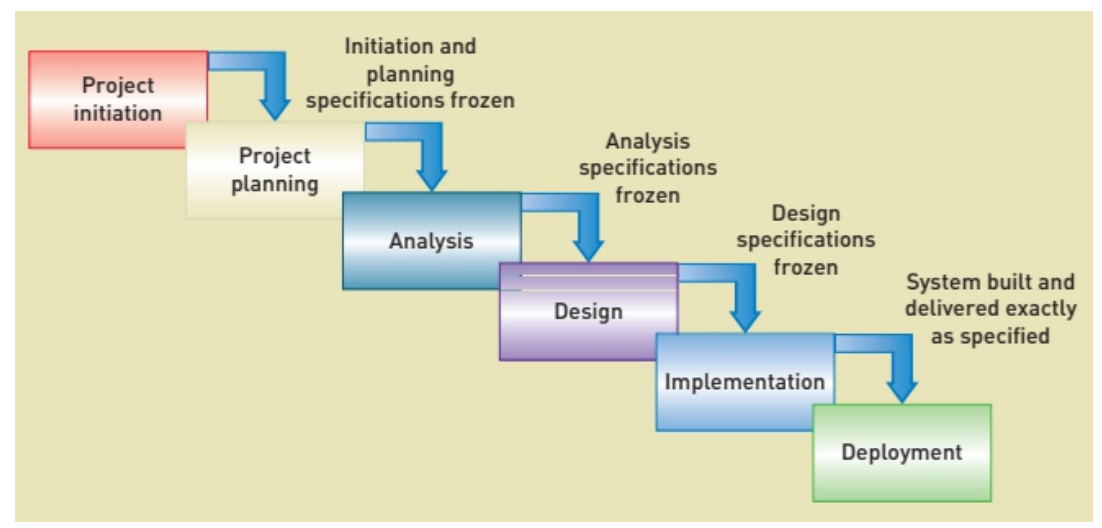

Gambar 2: Model Waterfall [11]

\section{Tahapan Metode Penelitian}

a. Analisis Masalah

Tahap ini merupakan tahapan dalam menemukan masalah dan menentukan rumusan dari permasalahan yang ada.

b. Pengumpulan Data

Pengumpulan data dan informasi penunjang dalam dilakukan dalam tahap ini.

c. Studi Literatur

Tahapan dalam pencarian penelitian terkait dan metode pengembangan yang akan diterapkan dalam pengembangan perangkat lunak.

d. Pengembangan

Tahap ini menguraikan tahapan dalam pengembangan perangkat lunak yang akan diimplementasikan.

e. Penyampaian Produk

Tahap ini membahas tentang penyampaian akhir yang dilakukan untuk pengguna aplikasi agar dapat menggunakannya secara langsung dan pemilihan nama Domain yang digunakan dalam mengakses aplikasi ini.

\section{Tahapan Pengembangan Sistem}

Tahap pengembangan sistem ini terdiri dari enam tahap. Tahapan tersebut meliputi: http://journal.thamrin.ac.id/index.php/jtik/article/view/526 
a. Inisiasi Proyek

Tahap ini dilakukan untuk menginisiasi proyek pekerjaan aplikasi e-infak.

b. Perencanaan Proyek

Perencanaan proyek dilakukan untuk menentukan jadwal penyelesaian proyek dan pembagian tugas untuk pengerjaan aplikasi.

c. Analisis

Tahap ini dilakukan untuk menentukan kebutuhan dari suatu perangkat lunak, baik hardware, software, netware, dan organiware.

d. Desain

Tahap ini membahas tentang penyusunan model perangkat lunak baik itu desain database ataupun juga desain proses yang digunakan untuk mengembangkan aplikasi e-infak ini.

e. Implementasi

Fase ini menterjemahkan desain ke dalam pemrograman aplikasi dan desain antarmuka aplikasi serta pengujian terhadap aplikasi e-infak setelah dikembangkan.

\section{f. Deployment}

Pengunggahan ke media hosting dan konfigurasi nama Domain dilakukan pada fase ini.

\section{HASIL DAN PEMBAHASAN}

[12] membahas kelayakan dan keandalan pengembangan sistem layanan donasi amal menggunakan teknologi blockchain berdasarkan meningkatnya permintaan layanan kompleks yang dihadapi oleh operator amal karena epidemi COVID-19. makalah ini berfokus pada praktik masalah dana sumbangan amal dan alokasi materi, serta rilis dan berbagi informasi, amal organisasi donasi, dan organisasi swakelola. [13] menjelaskan implementasi produk wakaf uang pada Bank CIMB Niaga dapat dikatakan relatif baik karena sudah merespon keinginan dan kebutuhan waqaf dan sudah menggunakan teknologi seperti aplikasi e-salam sebagai financial technology. Salah satunya dengan 
memastikan penyelenggaraan layanan pembayaran yang menggunakan QRIS di Indonesia dapat berjalan dengan baik. Dari studi literatur yang telah dilakukan, pengembangan aplikasi e-infak ini dikembangkan dengan menerapkan implementasi menggunakan QRIS pada aplikasi berbasis web yang bekerja sama dengan DMI Kota Depok. Aplikasi ini memiliki beberapa fitur yaitu: melihat kegiatan rutin masjid, menampilkan halaman donasi berupa QRIS pada masjid yang sudah terdaftar. Fungsi pada aplikasi ini terlihat pada Gambar 3.

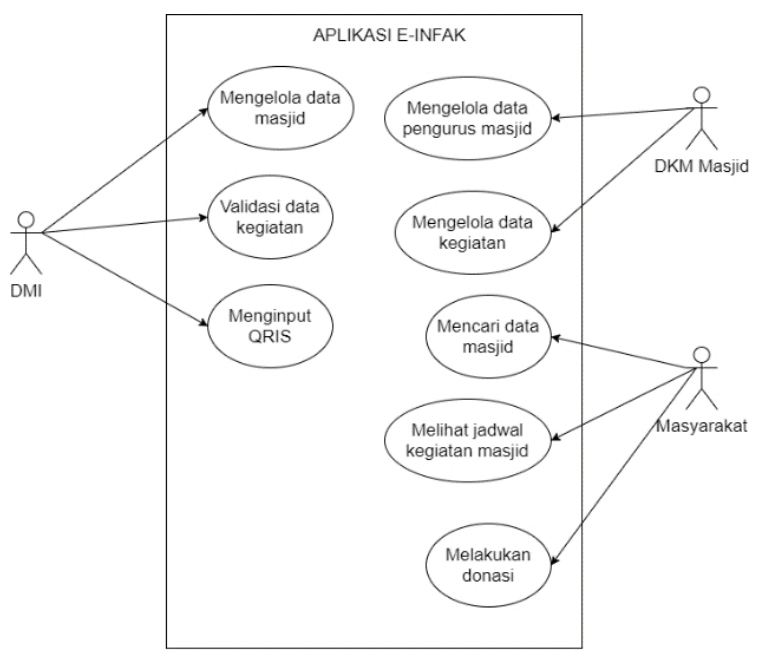

Gambar 3: Diagram Use Case

Pembuatan QRIS akan dilakukan dengan cara pihak DMI Kota Depok bekerja sama dengan salah satu Bank milik pemerintah atau Bank lain yang sudah memiliki ijin dari Bank Indonesia (BI) untuk mengeluarkan QRIS. QRIS yang sudah terdaftar untuk masjid akan diinputkan melalui aplikasi e-infak berbasis web. Prosedur untuk mendapatkan QRIS terlihat pada Gambar 4.

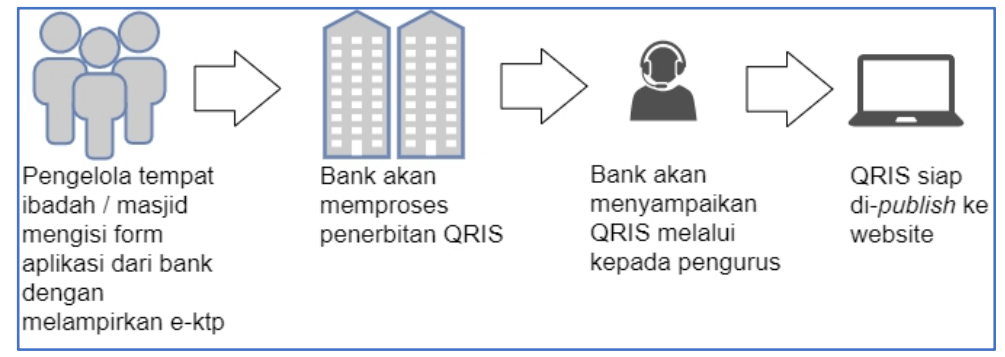

Gambar 4: Alur Pembuatan QRIS

QRIS yang sudah di-publish pada aplikasi e-infak ini untuk selanjutnya dapat dipindai menggunakan aplikasi multi-payment yang umum digunakan masyarakat Indonesia pada umumnya seperti: aplikasi E-Banking, DANA, OVO, GO-Pay, dan yang lainnya. Arsitektur aplikasi e-infak ini terdiri Web Server dan Database Server. Framework yang digunakan dalam pengembangan aplikasi ini menggunakan Django dengan Bahasa Pemrogramannya adalah http://journal.thamrin.ac.id/index.php/jtik/article/view/526 
Python. Aplikasi ini memiliki tiga user yang telah dijelaskan pada use case diagram. User "DMI" merupakan administrator pada aplikasi ini. User "DMI" dan user "DKM Masjid" yang menggunakan akun untuk dapat melakukan fungsionalnya pada aplikasi ini. Tampilan halaman administrator dapat dilihat pada Gambar 5. Administrator memiliki hak akses penuh terhadap data masjid.

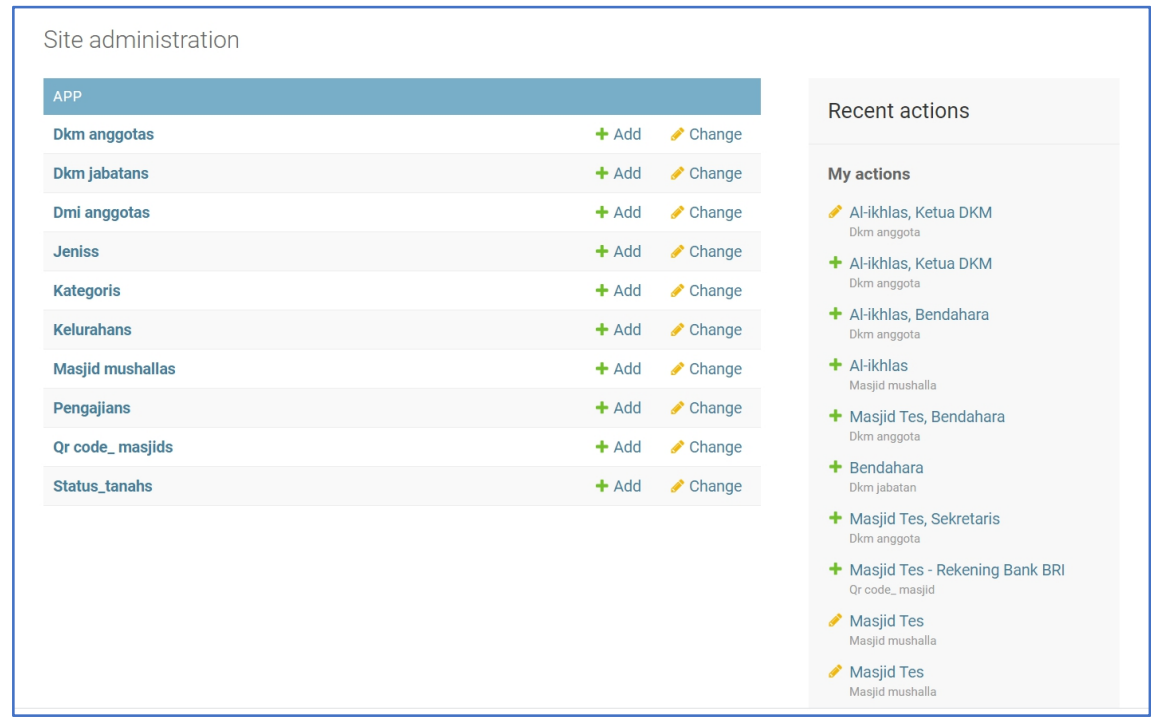

Gambar 5: Halaman Administrator

Administrator dapat menambahkan lokasi masjid dengan meng-copy-kan alamat url lokasi masjid pada Google map ke dalam aplikasi. QRIS akan diinputkan melalui halaman administrator yang terlihat pada Gambar 6. QRIS yang diinputkan ini nantinya akan muncul dihalaman public. Setiap masjid akan mendapatkan kode QRIS masingmasing. File QRIS yang dapat di-upload adalah bertipe image.

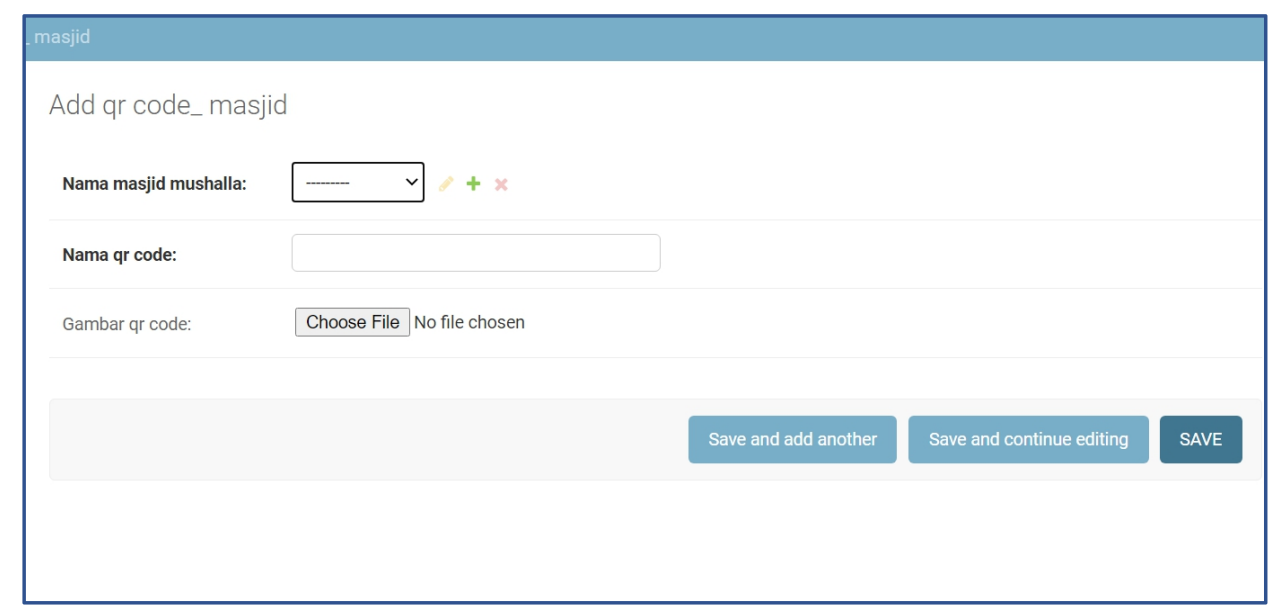

Gambar 6: Halaman upload QRIS

Halaman public pada aplikasi ini ditampilkan suatu data masjid yang dapat dicari oleh masyarakat atau user umum. Aplikasi ini tidak hanya digunakan untuk berdonasi saja akan tetapi dapat digunakan juga bagi para jamaah yang ingin mengetahui agenda kajian http://journal.thamrin.ac.id/index.php/jtik/article/view/526 
di masjid tersebut. Halaman utama public pada aplikasi ditunjukkan pada Gambar 7. Masyarakat dapat melihat kajian dengan cukup mencari data masjid pada tabel pencarian yang sudah disediakan. Pencarian dapat dilakukan dengan mengetikkan kata kunci. Kata kunci yang digunakan dapat berupa nama masjid, tema pengajian, lokasi, waktu, dan pemateri. Masjid yang sudah terpilih untuk selanjutnya dapat dilihat detail kegiatan dan agendanya dengan mengakses tombol "Lihat" pada tabel.
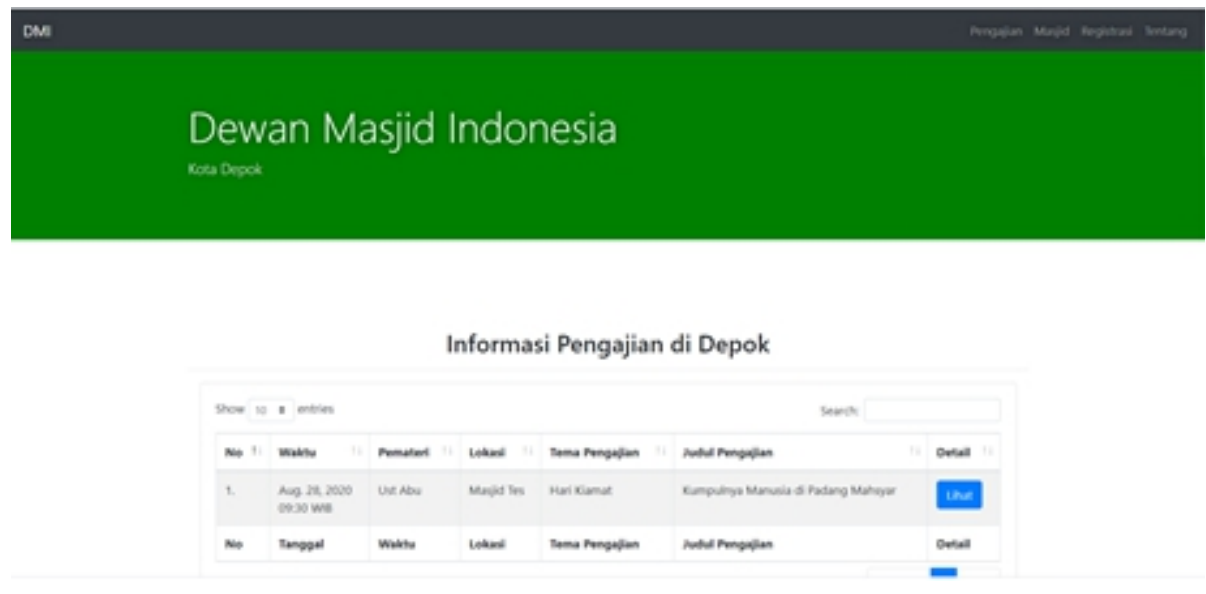

Gambar 7: Halaman Public

Proses utama berikutnya adalah masyarakat dalam melakukan donasi langsung terhadap masjid melalui halaman utama ini setelah memilih masjid yang diinginkan. User akan melihat lokasi masjid terlebih dahulu untuk memastikan masjid yang ingin diberikan donasi berada sesuai dengan lokasinya. QRIS dari masjid akan berada pada tampilan detail masjid berikut sejarah dan profil dari masjid. Tampilan QRIS dapat dilihat pada Gambar 8 .

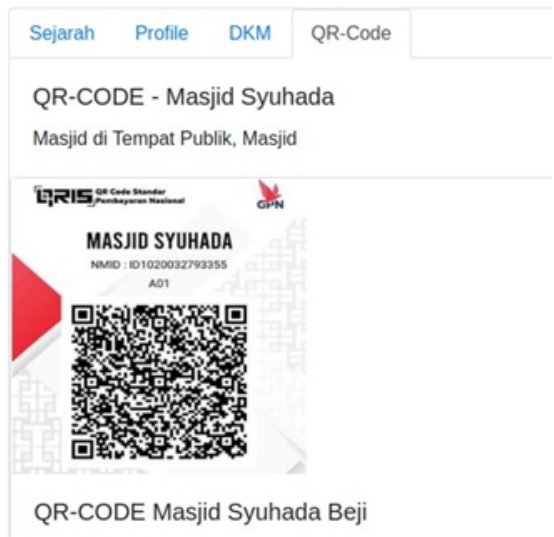

Gambar 8: Tampilan QRIS Masjid

Kode QRIS yang telah tampil akan dapat langsung dipindai oleh user atau masyarakat menggunakan aplikasi payment yang sudah dimilikinya. Alur penggunaan aplikasi 
terlihat pada Gambar 9. Aplikasi payment yang digunakan tidak dibatasi pada satu payment gateway saja. Hasil dari pindai QRIS tersebut user akan diarahkan pada pembayaran donasi ke nomor rekening dari Masjid yang dituju. Apabila ingin berdonasi kembali ke masjid yang lainnya, user dapat kembali ke halaman utama dari aplikasi dan melakukan pencarian data masjid yang ingin diberikan donasi. Proses pindai QRIS ini harus membutuhkan koneksi internet untuk dapat membaca kode QRIS tersebut. Aplikasi ini juga masih dapat memungkinkan untuk menambahkan skema donasi dengan menggunakan QR Code khusus seperti OVO, GO-PAY, atau DANA. Prosedur yang dilakukan pihak masjid untuk mendapatkan QR Code khusus ini akan berbeda mengikuti aturan daripada payment gateway yang digunakan.

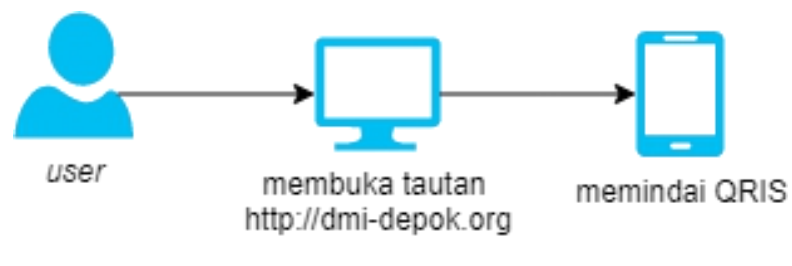

Gambar 9: Alur User Melakukan Donasi (Infak)

\section{SIMPULAN}

Aplikasi yang dikembangkan ini telah dapat diakses melalui public. Aplikasi ini menjawab solusi donasi di masa pandemi COVID-19 agar kegiatan operasional masjid dapat berjalan dan kegiatan kajian keagamaan pun dapat berjalan dengan baik. Penggunaan QRIS menjadikan fleksibilitas pada masyarakat untuk menggunakan aplikasi payment gateway yang diinginkan.

\section{REFERENSI}

[1] M. Chinazzi et al., "The effect of travel restrictions on the spread of the 2019 novel coronavirus (COVID-19) outbreak," Science (80-. )., vol. 368, no. 6489, pp. 395-400, 2020, doi: 10.1126/science.aba9757.

[2] I. Ali and O. M. L. Alharbi, "COVID-19: Disease, management, treatment, and social impact," Sci. Total Environ., vol. 728, p. 138861, 2020, doi: 10.1016/j.scitotenv.2020.138861.

[3] D. L. Blustein, R. Duffy, J. A. Ferreira, V. Cohen-Scali, R. G. Cinamon, and B. A. Allan, "Unemployment in the time of COVID-19: A research agenda," J. Vocat. Behav., vol. 119, no. May, pp. 1-4, 2020, doi: 10.1016/j.jvb.2020.103436.

[4] M. Z. Tay, C. M. Poh, L. Rénia, P. A. MacAry, and L. F. P. Ng, "The trinity of http://journal.thamrin.ac.id/index.php/jtik/article/view/526 
COVID-19: immunity, inflammation and intervention," Nat. Rev. Immunol., vol. 20, no. 6, pp. 363-374, 2020, doi: 10.1038/s41577-020-0311-8.

[5] Y. Qiu and C. Liu, "An in-kind charitable donation system app design practice driven by social innovation design concept," Proc. - 2019 6th Int. Conf. Inf. Sci. Control Eng. ICISCE 2019, pp. 141-145, 2019, doi: 10.1109/ICISCE48695.2019.00038.

[6] A. T. Purnomo, Y. S. Gondokaryono, and C. S. Kim, "Mutual authentication in securing mobile payment system using encrypted QR code based on public key infrastructure," Proc. 2016 6th Int. Conf. Syst. Eng. Technol. ICSET 2016, pp. 194-198, 2017, doi: 10.1109/FIT.2016.7857564.

[7] O. J. Okesola, A. A. Adebiyi, A. A. Owoade, O. Adeaga, O. Adeyemi, and I. Odun-Ayo, "Software Requirement in Iterative SDLC Model," in Software Requirement in Iterative SDLC Model, 2020, pp. 26-34, [Online]. Available: https://link.springer.com/chapter/10.1007/978-3-030-51965-0_2.

[8] K. Bhavsar, V. Shah, and S. Gopalan, "Scrumbanfall: An Agile Integration of Scrum and Kanban with Waterfall in Software Engineering," Int. J. Innov. Technol. Explor. Eng., vol. 9, no. 4, pp. 2075-2084, 2020, doi: 10.35940/ijitee.d1437.029420.

[9] W. Apriani, “Jurnal Mantik Jurnal Mantik," Sist. Pendukung Keputusan Pemilihan Pimpinan Dengan Metod. Multi Attrib. Util. Theory di PT. Sagami Indones., vol. 3, no. 2, pp. 10-19, 2019.

[10] O. M. Yusop and N. Mahbub, "Experiences in Software Development Model Selection and MVC Design Pattern Implementation for Kuala Lumpur City Hall Traffic Offence Management System,” vol. 7, no. 1, 2019.

[11] J. W. Satzinger, R. B. Jackson, S. D. Burd, R. B. Jackson, and S. D. Burd, Systems Analysis and Design in A Changing World (6th Edition), vol. 5th ed.. 2012.

[12] H. Wu and X. Zhu, "Developing a Reliable Service System of Charity Donation during the Covid-19 Outbreak," IEEE Access, vol. XX, pp. 1-1, 2020, doi: 10.1109/access.2020.3017654.

[13] M. E. . MUHAMMAD IKHSAN HARAHAP, Implementasi Produk Wakaf Uang Melalui Lembaga Keuangan Syariah, no. 0705163038. 2019. 